"This is the peer reviewed version of the following article: [Journal of Advanced Nursing, 2017, 73 (5), pp. 1051 - 1065], which has been published in final form at [http://dx.doi.org/10.1111/jan.13185]. This article may be used for non-commercial purposes in accordance with Wiley Terms and Conditions for SelfArchiving." 
Nicholls R., Perry L., Duffield C., Gallagher R.\& Pierce H. (2016) Barriers and facilitators to healthy eating for nurses in the workplace: an integrative review. Journal of Advanced Nursing 2016. doi: 10.1111/jan.13185

\section{Barriers and facilitators to healthy eating for nurses in the workplace: an integrative review}

\section{Running head: Nurses diet at work}

Rachel NICHOLLS, Research Fellow, Faculty of Health, University of Technology Sydney, New South Wales, Australia, PhD, MPH, BA, rachel.nicholls@uts.edu.au Tel: +61 295148049

Lin PERRY, Professor of Nursing Research \& Practice Development, Faculty of Health, University of Technology Sydney, Australia, PhD, MSc, RN.

Christine DUFFIELD, Professor of Nursing and Health Services Management and Director, Centre for Health Services Management, Faculty of Health, University of Technology Sydney, New South Wales and Edith Cowan University, Perth, Western Australia, PhD, MHP, RN.

Robyn GALLAGHER, Professor of Nursing, Charles Perkins Centre, Sydney Nursing School, University of Sydney, Sydney, New South Wales, PhD, MN, RN.

Heather PIERCE, BAppSc, RM, PhD candidate, Faculty of Health, University of Technology Sydney, Australia

Conflict of interest: No conflict of interest was declared by the authors in relation to the study itself. Note that Robyn Gallagher is a JAN editor but, in line with usual practice, this paper was subjected to double blind peer review and was edited by another editor.

\section{Funding Statement:}

This research received no specific grant from any funding agency in the public, commercial, or not-for-profit sectors. 


\begin{abstract}
Background: There is growing recognition of the influence of the workplace environment on the eating habits of the workforce, which in turn may contribute to increased overweight and obesity. Overweight and obesity exact enormous costs in terms of reduced well-being, worker productivity and increased risk of non-communicable diseases. The workplace is an ideal place to intervene and support healthy behaviours. This review aimed to identify barriers and facilitators to nurses' healthy eating in the workplace.
\end{abstract}

Design: Integrative mixed method review

Data sources: Five electronic databases were searched: CINAHL, MEDLINE, PROQUEST Health and Medicine, ScienceDirect and PsycINFO. Reference lists were searched. Included papers were published in English between 2000-2016. Of 26 included papers, 21 were qualitative and 5 quantitative.

Review methods: An integrative literature review was undertaken. Quality appraisal of included studies used standardised checklists. A social-ecological framework was used to examine workplace facilitators and constraints to healthy eating, derived from the literature. Emergent themes were identified by thematic analysis.

Results: Review participants were Registered, Enrolled and/or Nurse Assistants primarily working in hospitals in middle or high income countries. The majority of studies reported barriers to healthy eating related to adverse work schedules, individual barriers, aspects of the physical workplace environment and social eating practices at work. Fewfacilitators were reported. Overall, studies found the workplace exerts a considerable negative influence on nurses' dietary intake.

Conclusion: Reorientation of the workplace to promote healthy eating among nurses is required.

Keywords: literature review, systematic review, mixed method, integrative review, nurses, healthy eating, diet, overweight, obesity, workplace, barriers, facilitators. 


\section{Summary statement}

\section{Why is this review needed?}

- Workplace conditions in health facilities can contribute to nurses' poor dietary practices

- There has been little effort to synthesise literature which identifies barriers and facilitators to healthy eating for nurses despite unique factors in the workplace which negatively influence the choice and availability of food and the eating behaviours of nurses.

\section{What are the key findings?}

- Organisational factors such as long working hours and shift work feature prominently as barriers to a healthy diet for nurses. Social factors (e.g. eating practices with colleagues), personal characteristics (e.g. self-efficacy, motivation, knowledge) and features of the physical environment (e.g. lack of availability of healthy food in onsite cafeterias, vending machines) also play a role in determining nurses' healthy eating behaviours in the workplace.

- Features of the social and physical environment can influence healthy eating by, for example, increasing the availability of fresh food for evening/night shift workers, adequate food preparation and storage facilities and the influence of colleagues to eat healthily.

\section{How should the findings be used to influence policy/practice?}

- Identifying barriers and facilitators to healthy eating in the work place is important to indicate where to intervene and promote organisational and behaviour change.

- Opportunities are identified for management and staff at health facilities to be change agents to develop and maintain a healthier nursing workforce. 


\section{INTRODUCTION}

The nursing and midwifery workforce faces growing healthcare demands from an ageing population and an increasing burden of non-communicable diseases; because of this, nurses' own health status is a consideration for how these demands will be met (Campbell et al. 2013). Evidence suggests that many nurses are engaging in unhealthy 'lifestyle' behaviours and have relatively poor health (Zapka et al. 2009, Tucker et al. 2010, Phiri et al. 2014, Perry et al. 2015). Physical inactivity and poor dietary practices have been reported in nursing populations and the majority of nurses are overweight or obese (Tucker et al. 2010, Blake et al. 2011, Bogossian et al. 2012, Perry et al. 2015, Perry et al. 2016). Paradoxically, nurses' workplace conditions may be contributing to poor dietary practices: a major determinant of overweight and obesity. However, there has been little effort to synthesise literature which addresses barriers and facilitators to healthy eating despite unique factors of the workplace which may influence the choice and availability of food and the eating behaviours of nurses.

\section{Background}

The health status of the nursing workforce has gained increasing attention in recent years. This may at least in part relate to the increasing average age of the workforce, but another concern is the increasing prevalence of overweight and obesity, reported as similar, or higher than that of the general population (Bogossian et al. 2012, Perry et al. 2015, Kyle et al. 2016). A recent study of nursing staff in Australia, New Zealand (NZ) and the United Kingdom (UK) (n 4996), reported almost two-thirds outside the healthy weight range, with the prevalence of obesity $1.7 \%-3.7 \%$ higher than that of the general population (Bogossian et al. 2012). Worldwide, overweight rates amongst nurses measured by body mass index (BMI) have ranged from 18\% to 53\% (Kivimaki et al. 2001, Tucker et al. 2010, Blake et al. 2011, Han et al. 2011, Kim et al. 2013) and rates of obesity from 7.4\% to 28\% (Miller et al. 2008, Zapka et al. 2009, Ogunjimi et al. 2010, Tucker et al. 2010, Blake et al. 2011, Huth et al. 2013, Kim et al. 2013). Factors contributing to obesity are highly complex and multifactorial, but at the simplest level is due to an increased consumption of high calorific foods without an equal increase in physical activity (World Health Organization, 2015). With nutrition playing a substantial role in obesity and associated chronic diseases, as well as general health, this review examines barriers and facilitators to healthy eating identified as having an impact on nurses' eating behaviours in the workplace. 
For the purposes of this review, healthy eating behaviours in nurses were defined in line with guidelines from Lowden et al. (2010). They encompass: (i) the timing and frequency of eating; (ii) meal composition; (iii) food composition; (iv) the habitual average intake of energy and essential non-energy yielding nutrients (Figure 1).

Among health workers, the prevalence of obesity and chronic disease has been linked to the influence of shift work on metabolism and eating behaviours and directly related to body fatness (Di Lorenzo et al. 2003, Lowden et al. 2010). Small increases in BMI, overweight and obesity have been found in shift workers compared with day only workers or those who never worked shifts (Kivimaki et al. 2001, Zhao et al. 2011, Zhao et al. 2012a, Kim et al. 2013, Tada 2014). Obesity amongst nurses significantly increases with increasing number of years working shifts (Kim et al. 2013) but there is a reduced risk of overweight, or decreased BMI, in nurses working part-time or casually and in those switching from shift work to daytime hours (Bogossian et al. 2012, Zhao et al. 2012b). Explanations include the impact of unsocial work schedules on eating behaviours: unfavourable work schedules limit access to fresh food and disrupt eating patterns, which in turn adversely affect metabolism (Han et al.2011, Nahm et al. 2012). Fatigue from working long hours and shift work may lead to reliance on high energy snack or convenience food (Waterhouse et al. 2003).

Studies examining workforce nutrition have reported nurses consuming similar low quantities or fewer fruit and vegetables compared with populations (Perry et al. 2015, Ratner \& Sawatzky 2009). Up to two-thirds of nursing samples did not meet recommended dietary guidelines (Zapka et al. 2009, Malik et al. 2011). Comparing the diets of nurse shift workers with nurse day workers showed shift workers with higher consumption of confectionary and sugary beverages (Tada, 2014), although evidence concerning total energy intakes is somewhat contradictory (Reeves et al. 2004). Nurses report irregular meal frequency and unhealthy snacking behaviours (also linked to obesity). Night shift workers were particularly less likely to have regular, full meals (Nahm et al. 2012) and often replaced meals with unhealthy snacks and convenience food (Han et al. 2016). Many nurses also report skipping breakfast which may lead to impulsive snack 
intakes (Yoshizaki et al. 2010). Overall the nutritional intake of shift workers compared with day workers was less healthy and they tended to be overweight (Zhao et al. 2008).

Most studies focus on the impact of shift work and there is less recognition of other workplace factors having an impact on healthy eating. From an ecological health promotion perspective, the multiple determinants of workers' eating behaviours in the workplace include individual level factors (e.g. knowledge, motivation), social relationships, organisational characteristics and policies and the physical environment. These multiple levels of influence affect eating behaviours directly, through for example increasing the availability of healthy foods, or indirectly, through social norms (Stokols et al. 1996). Features of the workplace environment with an impact on eating habits include limited access to meals when canteens are closed outside 'traditional' work hours, but ready availability of junk food and soft drinks from vending machines (Faugier et al. 2001a, Phiri et al. 2014). The sharing of cakes and biscuits with other staff and gifts of chocolate from grateful patients are also common in nursing cultures (Cheung 2003).

\section{THE REVIEW}

Aim

The aim was to conduct an integrative systematic review to identify barriers and facilitators to healthy eating for working nurses.

\section{Design}

The design was informed by methods developed by Whittemore and Knafl (2005). This 'integrative' review approach allows for the inclusion of qualitative, quantitative and mixed methods studies and involves three key phases: (1) literature search using two search strategies (refer to search methods below); (2) data evaluation involving a thematic analysis process: data reduction, data display and drawing and verifying conclusions; and (3) presentation of conclusions.

\section{Literature search methods}

A search strategy was composed around the key elements of: 
Participants: Nurses of all grades and types were included (registered, enrolled, students, nursing assistants, etc.). Studies that included students and unqualified staff alongside qualified staff were included; those that recruited only students or unqualified assistants were excluded.

Context: The review targeted nurses' workplaces in any country. All nursing work settings were included but initial searching identified that 'site' terms (such as hospital, primary care) did not help identify studies. Terms that identified studies as workplace-based included 'occupational health', 'workplace' or 'shift-work'.

Topic: The review targeted food and eating and factors which were barriers and facilitators to eating healthily, defined in line with guidelines from Lowden et al. (2010) (Figure 1).

The search strategy (detailed in Supplementary Table 1) applied MESH terms and text words in all/any fields or restricted to the title, abstract or keyword. CINAHL, MEDLINE, ProQuest Health and Medicine, ScienceDirect and PsycINFO electronic databases were searched for papers published in English between 2000 - 2015. Hand searches of reference lists, Google Scholar and websites with related content were also carried out.

\section{Inclusion and exclusion criteria}

A study was eligible for inclusion if: (1) original data were reported; (2) participants were nurses (of any grade / type as long as the study at least included qualified nurses) in any country; and (3) results included perceived/identified barriers and/or facilitators to healthy eating in the workplace. Quantitative and qualitative studies with any type of design were included. Exclusion criteria were studies with only students as participants and non-peer-reviewed literature.

After duplicate citations were excluded, one reviewer $(\mathrm{RN})$ screened titles, abstracts and, where necessary, full text, to create a list of potentially relevant full text papers. Another reviewer (HP) independently assessed the papers for inclusion. Discrepant views were resolved by group discussion and consensus to create the final list of included papers.

\section{Search output}


Database searches yielded 1751 publications and a hand search of reference lists identified 16 further papers; this was reduced to 1740 after removing duplicates and to 26 after applying inclusion/ exclusion criteria. Of included studies, 21 used quantitative methods (cross-sectional surveys only) and 5 qualitative methods (interviews and focus groups) (Table 1). The Preferred Reporting Items for Systematic Reviews and Meta-Analyses (PRISMA) guidelines were used to report the review process (Figure 2).

\section{Quality appraisal}

Included studies were evaluated using two quality frameworks. Using Glasziou et als (2001) appraisal framework, we assessed the reliability of quantitative studies, rating studies to a maximum score of five (Supplementary Table 2). Qualitative studies were assessed using the Critical Appraisal Skills Programme (CASP) (2006) ten question appraisal tool (Supplementary Table 3). Two researchers (RN, HP) independently assessed the studies using these checklists and discussed and resolved any uncertainty.

\section{Quantitative studies:}

Only two of the 21 quantitative studies fulfilled all of Glaszious' methodological criteria. In the remainder, selection and measurement bias may have distorted results: participants were not randomly or consecutively selected in 13 studies and respondents and non-respondents were not compared in 12 of the studies with participation rates less than $60 \%$. Nine studies did not report survey validation or standardisation. Five studies did not report ethical review.

All 21 studies were included because of the relevance of their data to this review, with quality limitations born in mind. As this review was primarily concerned to identify barriers and facilitators to healthy eating, rather than impact or effectiveness, quality assessment was primarily concerned with establishing and excluding instances where data or conclusions might be unreliable and to enable consideration of findings in context (see Supplementary Tables $2 \& 3$ ).

\section{Qualitative studies:}


Appraisal using the CASP qualitative methodological assessment tool indicated four of the included qualitative papers were of good quality, with the remaining study of limited quality as it failed to adequately describe participant recruitment, data analysis or ethical approval. No qualitative study considered the relationship between the researcher and participants or other possible power imbalances despite obvious potential for nurses to bias their responses so as to not jeopardise their employment (Supplementary Table 3).

\section{Data abstraction}

For all included papers, methodological data, participant roles, settings, study limitations and relevant text that referred to the research question were extracted into a data table (Supplementary Tables $1 \& 4)$.

\section{Synthesis of results}

The methods used to synthesise results was based on the technique of thematic synthesis of mixed methods described by Whittemore and Knafl (2005), which included: data reduction, data display (in tables, including quality) and drawing and verifying conclusions. In this approach, the relationships within and between studies were explored using different types of data. The rationale for using an integrative approach was that there was insufficient quantitative or qualitative research to explain the issue and this method permits multiple perspectives to be presented. While basic statistical data are used in this review, words and text are primarily used to summarise and explain the findings.

We descriptively summarised data from the quantitative results of included articles, all of which collected data through questionnaire surveys. We extracted themes presented in the findings of the qualitative articles, which collected data of personal experiences through interviews, observation and focus groups.

An a priori organising framework based on social-ecological theory (WHO 1986, Stokols 1996) was developed to provide a focus for the first part of the data analysis (deductive approach). The framework was developed to examine the main level at which the features of the workplace enable and constrain healthy eating in the workplace and are: organisational, 
environmental, social and individual features. The data was grouped according to the overarching themes and discussed among the group to reach consensus. A thematic analysis was undertaken to identify emergent patterns across and in the data and was coded 'line by line' by researchers. Data were progressively reviewed and categorised using an inductive approach, until no new concepts emerged (Creswell 2007). Using both deductive and inductive approaches allows new inquiries to build on previous insights in the field (Miles \& Huberman 1994). NVivo qualitative software package for data management (2012) was used to aid analysis. The basic thematic coding structure is presented in Supplementary Table 5.

\section{RESULTS}

Of 21 included quantitative papers, 17 were cross sectional in design and used self-administered questionnaires (Geliebter et al. 2000, Faugier et al. 2001a, Cheung 2003, Jinks et al. 2003, Waterhouse 2003, Brown et al. 2007, Kirk et al. 2008, Miller et al. 2008, King et al. 2009, Zapka et al. 2009, Wong et al. 2010, Parker, 2011, Sahu et al.2011, Nahm et al. 2012, Naghaspour et al. 2013, Blake \& Patterson 2015, Zhu et al. 2014) and two analysed cross sectional survey data (Fernandes et al. 2013, Smith et al. 2013). Another two used cross-sectional data from longitudinal studies (Han et al. 2011, Han et al 2012). Of a total of five qualitative papers, three conducted interviews with nurses (Persson et al. 2006, Aranda \&McGreevy 2014, Cass et al. 2014); one conducted interviews and observations at facilities (Faugier et al. 2001b) and one used interviews and focus groups (Phiri et al. 2014) (Table 1).

Participants in the included papers were Registered Nurses, Enrolled Nurses, District Nurses, Practice Nurses, Licenced Practical Nurses, Nurse Aides, Ward assistants and Health Visitors. They worked in a variety of settings; most were hospitals, but primary care, community and tertiary educational settings were represented. Studies were sited in lower-middle, high-middle and high income countries, as defined by World Bank criteria (The World Bank, 2016).

\section{Organisational barriers and facilitators to healthy eating}


Long work hours, shift work, a high workload, low staffing levels and short/few work breaks were all reported as organisational barriers to nurses' healthy eating. No organisational factors that facilitated healthy eating were reported.

\section{Long working hours}

Nurses commonly attributed unhealthy eating habits (such as skipping meals, not eating regular meals and high consumption of junk food and coffee) to long and demanding working hours and domestic demands outside of work. The resulting fatigue left little time or energy for preparation of healthy meals for United States (US) and South African nurse participants (Phiri et al. 2014, Nahm et al. 2012, Fernandes et al. 2013). Poor eating habits were attributed to long professional and domestic work hours per week amongst female Brazilian nurses (mean of 77.1 hours for females and 73.7 for males). Male Brazilian nurses had higher consumption of alcohol, coffee and fried food and a lower consumption of fruit and vegetables, but this was not associated with long working or domestic hours (Fernandes et al. 2013). Nurses working full-time or long working hours in an US study were more likely to be overweight or obese and have poor quality of sleep. These factors were thought to have an impact on sustaining healthy behaviours (Han et al. 2011).

An investigation of US nurses with unfavourable work schedules (i.e. long work hours, weekly burden, on-call/overtime and lack of rest) found they slept less, reported less restful sleep and more stressful working conditions and were more likely to look after dependents than their counterparts with more favourable schedules. Obesity among nurses with unfavourable schedules was attributed to these factors, but also to difficulty accessing healthy food and few opportunities to engage in physical activity (Han et al. 2012).

\section{Shift work}

Shift work was identified as a barrier to nurses' healthy eating behaviours. Over a mean of 7.6 years, late shift nurses, nurse aides and security personnel $(n=49)$ (in USA) reported greater weight gain (mean weight of $4.3 \mathrm{~kg}$ ) than the day shift group who had worked day shifts over a mean 10.1 (SD 8.4) years (mean weight gain of $0.9 \mathrm{~kg} ; \mathrm{n}=36$ ). However, there was no significant difference in BMI between the groups (Geliebter et al. 2000). Explanations for the shift-related 
increase in weight centred on changes in normal eating habits which occurred when working shifts, particularly for late-shift workers, who ate more, ate the last daily meal later and had fewer meals than the comparative day shift group (Geliebter et al. 2000). Furthermore, shift duties were positively associated with abnormal eating behaviours in nurses working in a Hong Kong hospital (including eating in response to negative emotions and overeating after abandoning a diet) (Wong et al. 2010).

Snacking behaviours of United Kingdom (UK) shift workers were examined in a study where three-hourly self-assessments were completed by one group of 50 day workers from a research institute and another group of 43-night shift nurses. Night shift workers ate more snacks than day workers and were more likely to snack their way through a night shift than eat a complete meal (Waterhouse, 2003). This was supported by studies which compared late shift and day or rotating shift nurses' eating habits and found late shift working nurses ate a higher number of snacks and fewer meals (India) (Sahu et al. 2011); had higher food intakes but ate fewer meals (UK) (Geliebter et al. 2000); with poorer food choices which contributed to nutritional deficiencies (Iran) (Naghashpour et al. 2013). Swedish nurses also reported craving sugar and high carbohydrate food on the day following a night shift due to feelings of extreme fatigue. As a result, they were more likely to choose meals that were quick and easy to prepare - convenience food usually high in salt, fat and/or sugar (Persson et al. 2006).

\section{Work Stress}

Long working hours with a high workload are considered stressful by many nurses and nurses in the USA with higher perceived stress levels were more likely to engage in disordered eating, including thinking about or eating when stressed and upset (King et al. 2009). Swedish and US nurses described emotional eating as a coping strategy when stressed (Persson et al. 2006, Nahm et al. 2012), but this was not supported in a study of job stress and BMI where there was no association found (Han et al. 2011). Furthermore, hospital nurses in the US who perceived greater work stress and stressful working conditions reported healthier diets compared with those who disagreed or were unsure their job was stressful (Zapka et al. 2009). Thus, it was unclear overall whether or to what degree work stress contributed to unhealthy eating in nurses. 


\section{Physical workplace environment}

\section{Limited access to healthy food; inadequate food storage and preparation areas}

The physical environment plays a major role in determining health behaviours and the hospital environment, in particular, may have an impact on nurses eating behaviours. Busy UK, South African and US hospital shift workers reported they were often unable to access healthy food outside 'office hours' because food ran out or only a limited or non-existent choice of fresh, healthy food and vegetarian options were available to nurses working evening or night shift in particular (Faugier et al. 2001a, Nahm et al. 2012, Phiri et al. 2014). An exception to this was a large study ( $\mathrm{n}=9541$ nurses) sited in Canadian hospitals and long-term care facilities which found more night shift $(15.1 \%)$, than evening $(8.7 \%)$, day shift $(10 \%)$ or mixed shift nurses $(7.7 \%)$ had healthy eating options available during shifts worked. However, access to healthy food was limited overall, with $41.2 \%(\mathrm{~N}=3567)$ of participants reporting healthy food not being available at all (Smith et al. 2013).

Healthy food was more expensive than junk food in staff cafeterias (Phiri et al. 2014, Nahm et al. 2012) and vending machines stocked with junk food or unappetising canteen food were often the only available source of food for UK night shift nurses working in six hospitals, one NHS Direct and one Walk-in centre (Faugier et al. 2001b). For staff who brought their own food, space to refrigerate, heat and prepare food were often considered inadequate, either because of lack of access to fridges or microwaves, or because the catering facilities were too far from their work area (Faugier et al. 2001b). In addition, catering facilities were often shared with patients and visitors and this was perceived as a problem by staff because of frequent interruptions (Faugier et al. 2001a).

\section{Variety and availability of healthy choices in health facility canteens}

An observational study of eight healthcare sites in the UK reported on- site cafeterias designated or aspiring to be accredited as 'health promoting hospitals' were perceived as more conducive to healthy eating practices. In all wards in one hospital, staff had access to refrigeration and microwave facilities and cold vending machines with healthy snacks (e.g. yoghurt, fresh fruit and sandwiches). The cafeterias were described as 'pleasantly decorated', offering a wide selection of 
healthy choices, salad bars, theme days and ready-made meals and sandwiches were kept outside the cafeteria for nurses on night shifts (Faugier et al. 2001a).

\section{Social barriers and facilitators in the workplace setting}

Three studies investigated barriers or enablers to healthy eating related to nurses' social work environment (Cheung 2003, Persson et al.2006, Phiri et al. 2014). Eating behaviours were reported as both positively and negatively influenced by nurses' interactions with colleagues, as meals were often shared and conversations about diet and exercise strengthened motivation to adopt healthier habits (Persson et al. 2006, Phiri et al. 2014). On the other hand, nurses also influenced each other to eat junk food and social eating practices usually involved 'treat' food such as cakes and pizza (Persson et al. 2006). South African nurse participants said their colleagues made them feel guilty if they did not eat the cakes that were regularly available in the workplace (Phiri et al. 2014). Chocolate is also regularly available as patients traditionally give chocolates to nurses as expressions of gratitude. In a UK study, nurses reported eating chocolates every day 'because they were there' or because they were hungry or stressed. The ready availability of chocolate could be difficult to refuse (Cheung 2003).

\section{Personal facilitators and barriers:}

Awareness of overweight status

A significant proportion of overweight and obese nurses do not perceive themselves as such and have been found to be no better than general populations at accurately classifying their weight (Miller et al. 2008, Zhu et al. 2014). This is a significant barrier to intervention and behaviour change because unless nurses identify their weight as a health risk they are unlikely to be motivated to lose weight. A UK survey ( $\mathrm{N}=409$ qualified nurses) found $32 \%$ misclassified their own weight status, including underweight nurses who inappropriately classified themselves as normal weight (Zhu et al. 2014). In Tonga, 54.5\% of nurses sampled inaccurately classified their own weight, although this was more accurate than the lay group (82.6\%) (Kirk et al. 2008) and in the USA, of 224 overweight nurse respondents, $24 \%$ did not accurately identify themselves as overweight or obese (Miller et al. 2008). 
About $40 \%$ of US nurses sampled who did not recognise themselves as overweight believed they were eating healthily and exercising regularly but were unable to lose weight (Miller et al. 2008). The authors point out that few were likely to have abnormal metabolism, so respondents were either not appropriately identifying a healthy diet/ exercise pattern or were failing to acknowledge their poor eating habits. Knowledge of obesity-related health risks was limited amongst these nurses (Miller et al. 2008).

\section{Knowledge of obesity prevention}

Knowledge of lifestyle modification (including adoption of a healthy diet) was 'mediocre' among the majority of non-professional South African nurses, with $60 \%$ of Enrolled Nurses and $58 \%$ of Nurse Assistants surveyed obtaining a score between 49\% to 59\%. Among professional nurses, $42 \%$ had mediocre and 54\% had good knowledge scores (a score between 60\%-79\%). Although no nursing group gained an excellent score, $20 \%$ of all nurses rated their own knowledge as 'excellent', suggesting a disjoint between perceived and actual knowledge (Parker et al. 2011). Lack of obesity prevention and lifestyle modification in curricula or continuing education programs was noted by nurses in other studies in the USA, Australia and UK (Miller et al. 2008, Cass et al. 2014, Brown et al. 2007).

\section{Self-efficacy and motivation}

The majority of nurses in a UK study (Blake \& Patterson 2015) reported only moderate levels of self-efficacy in being role models for healthy eating. There appeared to be a relationship between nurses' self-efficacy, their professional practice in promoting health to others and their own behaviours (Blake \& Patterson 2015). Nurses were more likely to undertake healthy behaviours themselves or be confident in promoting health to others if they had higher self-efficacy and were more likely to consume recommended amounts of fruit and vegetables a day, than those with lower levels of self-efficacy (Blake \& Patterson 2015).

Nurses lacked motivation to lose weight or eat the recommended daily intake of fruit and vegetables despite pressure to be good role models for their patients (Zapka et al. 2009). Of hospital staff in the UK ( $n=1,021$ total, $n=490$ nurses), 92\% believed it would be 'pretty tough' or 'almost impossible' to change their current health behaviours, even though $51.3 \%$ would like 
to improve their diet and over $60 \%$ reported being overweight (Jinks et al. 2003). The reasons for this were not been explored in this study, but nurses have indicated struggles with food and weight are related to uncomfortable emotions faced as part of their job (Aranda \& McGreevy 2014).

\section{DISCUSSION}

This review found that organisational and social factors, personal characteristics of nurses and features of the physical environment all play a role in determining nurses' healthy eating behaviours in the workplace. There were several shared barriers to maintaining healthy diets for nurses in middle and high income countries, particularly organisational factors such as unfavourable work schedules. These included long working hours and shift work in hospital nurses. Only one study came from a low income country (India) and this also reported the negative impact of shift work on eating behaviours. These barriers were reported in both the qualitative and quantitative research, providing greater credibility for the results. Unfavourable work schedules were implicated in unhealthy eating behaviours in the nursing workforce particularly when low staffing levels and high workloads left staff exhausted and time-poor, with limited time and energy for engaging in preventative behaviours, including preparation of fresh, healthy meals (Phiri et al. 2014, Faugier et al. 2001a). As a result, snacking on high calorie junk food increased because of the perceived energising effect or as an emotional coping strategy.

Paradoxically, in healthcare environments, junk food is often more easily accessible and cheaper than healthy alternatives, which are often unavailable as canteens are closed outside office hours and food preparation areas are inadequate or inaccessible (Zapka et al. 2009, Faugier et al. 2001b). Chocolates from patients are usually available and cakes and other sweet food are a common social feature in countries such as the UK, Sweden and South Africa (Cheung 2003, Persson et al. 2006, Phiri et al. 2014). Individual factors were also identified as significant: poor motivation and moderate self-efficacy related to healthy eating, inadequate nutrition knowledge and, for many, failure to recognise their own overweight/ obese status (Miller et al. 2008, Zapka et al. 2009, Zhu et al. 2014). Conversely, it should be noted that many nursing professionals were knowledgeable and motivated to practice healthy behaviours. 
Features of the social and physical environment provided the only enablers found in this review. The surroundings of some UK health facility cafeterias were pleasant; some offered healthy food and more attractive choices seeking designation as a 'health promoting hospital' (Faugier et al. 2001b). Colleagues could be important in motivating and supporting each other to eat well (Persson et al. 2006). However, most studies indicated significant obstacles in the workplace (and amongst nurses) to healthy eating, particularly in hospital settings and in countries worldwide.

One recent review synthesised data on the influence of shift work and stress on eating behaviours in nursing workforces (Buss 2012) and concluded that shift work may be a factor in nurses' risk for both obesity and unhealthy diet. The link between stressful working conditions, obesity and eating behaviours was difficult to determine because of inconsistent approaches to defining and measuring work stress. Two other systematic reviews examining nutrition and eating practices among shift workers in predominantly labouring occupations showed similar findings: shift workers in other professions had a higher frequency of food intake, but fewer meals and poorer nutrition quality compared with day workers (Amani \& Gill 2013, Zhao et al. 2008). Shift work is identified as a problem and one where the healthcare workforce and nursing in particular, should lead in demonstrating solutions.

It may seem self-evident that health facilities should be healthy workplaces, but nurses have long been dissatisfied with their working conditions and the negative impact on their health (Adams \& Bond 2000, Jinks et al. 2003). The connection between the workplace and well-being was underscored by the World Health Organisation (WHO) in 1998. The WHO created a platform for 'health promoting hospitals' to improve the health and well-being of patients, their families and staff (WHO and European Office for Integrated Health Care Services, 1988). In this approach, health promotion is oriented towards improving employee working conditions in addition to employee-led health promotion activities for patients, families and/or community (Johnson \& Baum 2001). Ad hoc staff health promotion programs (Whitehead 2006) fall well short of the WHO definition of the health promoting hospital, where the concepts of health promotion are incorporated into organisational structure and culture by means of organisational development (World Health Organisation, 1991). 
Evidence suggests work place health-promotion programs that include modification of the work environment have a positive impact on nutrition behaviours (Biener et al. 1999, Engbers et al. 2005, Sorensen et al. 2007, Anderson et al. 2009). Dietary intake has been positively influenced by strategies such as increasing the availability and variety of healthy food options (Engbers $e t$ al. 2006) and reducing the price of healthy food in work site cafeterias and vending machines (French et al. 2001). A recent systematic review of work site health-promotion programs found that fruit, vegetable and fat intake can be positively influenced by strategies such as labelling, expanded availability of healthy foods and targeted food placement (Engbers $e t$ al. 2005). Strengthening the social environment of the workplace may also be beneficial in changing unhealthy norms (Kristal et al. 1995, Biener et al. 1999) but organisational support and policy reform are needed for sustainable behaviour change (Goetzel et al. 2008). Health promotion action should be integral, designed to suit the context and supported by prevailing norms, rules and cultures (Groene et al. 2005).

This review highlights potential benefit for nurses and their managers and employers by implementing changes to address identified barriers and enabling factors. This may entail improving healthy food accessibility and facilities; the development and observance of healthy food policies; development and implementation of continuing education programs. More broadly, benefits could accrue from attention to workload, staff and shift schedules and capitalising on programs which build on colleague support for healthy eating.

\section{Limitations of included studies}

All included quantitative studies were descriptive cross-sectional or cross-sectional longitudinal in design. These designs limit generalizability of the findings, although five of the included studies had very large sample sizes from a variety of health facility and country settings, strengthening evidence of association. Participants were self-selected in the majority of studies and response rates varied from a low of $15.5-82 \%$, raising the issue of recruitment bias in some studies. This can in part be overcome by comparing features of responders and non-responders, but this was only attempted in a small number of the studies. Furthermore, measurement bias 
was also a possibility because many questionnaires used in these studies were not standardised or validated, or no information about this was provided.

In the qualitative papers, no researcher appeared to consider and disclose their relationship with their participants even though the kind of information that participants disclose may depend on the nature of their relationship with the researcher. In three studies no information was provided about reaching data saturation. As with cross-sectional studies, qualitative studies are unable to be generalised, but the generally consistent messages of all included studies provide a coherent picture of possible determinants of poor diets, overweight and obesity amongst the nursing workforce. However, it is suggested that the limited quality of individual quantitative studies indicate need for caution in interpreting the results as well as further research to address these limitations.

\section{CONCLUSION}

Identifying barriers and facilitators to engaging in healthy behaviours are the first steps to developing a healthy workplace for nurses. Review findings indicate avenues to intervene to effect organisational and behaviour change. By addressing the complexity of reasons for unhealthy eating in the workplace, change can be strategic and effective. This review identifies barriers but also opportunities for organisations and individuals to be change agents, to empower staff and develop and maintain a healthier workforce. This will require change at all levels individual, social and organisational, to policy, strategies and practice. Whilst not an inconsiderable undertaking, the potential benefits in terms of staff health and wellbeing and the potential knock-on effects for the community make this worthwhile. 


\section{Author Contributions:}

All authors have agreed on the final version and meet at least one of the following criteria (recommended by the ICMJE*):

1) substantial contributions to conception and design, acquisition of data, or analysis and interpretation of data;

2) drafting the article or revising it critically for important intellectual content.

* http://www.icmje.org/recommendations/ 


\section{REFERENCES}

Adams, A. \& Bond, S. (2000) Hospital nurses' job satisfaction, individual and organizational characteristics. Journal of Advanced Nursing, 32(3), 536-543.

Amani, R. \& Gill, T. (2013) Shiftworking, nutrition and obesity: implications for workforce health- a systematic review. Asia Pacific Journal Of Clinical Nutrition, 22(4), 505-515.

Anderson, L.M., Quinn, T.A., Glanz, K., Ramirez, G., Kahwati, L.C., Johnson, D.B., Buchanan, L.R., Archer, W.R., Chattopadhyay, S., Kalra, G.P. \& Katz, D.L. (2009) The effectiveness of worksite nutrition and physical activity interventions for controlling employee overweight and obesity: a systematic review. American Journal of Preventive Medicine, 37(4), 340-357.

Aranda, K. \& McGreevy, D. (2014) Embodied empathy-in-action: overweight nurses' experiences of their interactions with overweight patients. Nursing Inquiry,21(1), 30-38.

Biener, L., Glanz, K., McLerran, D., Sorensen, G., Thompson, B., Basen-Engquist, K., Linnan, L. \& Varnes, J. (1999) Impact of the Working Well Trial on the worksite smoking and nutrition environment. Health Education \& Behavior, 26(4), 478-494.

Blake, H., Malik, S., Mo, P.K.H. \& Pisano, C. (2011) 'Do as I say, but not as I do': Are next generation nurses role models for health? Perspectives in Public Health, 131(5), 231-239.

Blake, H. \& Patterson, J. (2015) Paediatric nurses' attitudes towards the promotion of healthy eating. British Journal of Nursing, 24(2), 108-112.

Bogossian, F., Hepworth, J., Leong, G., Flaws, D., Gibbons, K., Benefer, C. \& Turner, C. (2012) A cross-sectional analysis of patterns of obesity in a cohort of working nurses and midwives in Australia, New Zealand and the United Kingdom. International Journal of Nursing Studies, 49(6), 727-738.

Brown, I., Stride, C., Psarou, A., Brewins, L. \& Thompson, J. (2007) Management of obesity in primary care: nurses' practices, beliefs and attitudes. Journal of Advanced Nursing, 59(4), 329-341.

Buss J (2012) Associations between obesity and stress and shift work among nurses. Workplace Health \& Safety, 60(10), 453.

Campbell, J., Dussault, G., Buchan, J., Pozo-Martin, F., Guerra Arias, M., Leone, C., Siyam, A. \& Cometto, G. (2013) A universal truth: no health without a workforce. Forum report, third global forum on human resources for health, Recife, Brazil. Global Health Workforce Alliance and World Health Organization, Geneva.

Cass, S., Ball, L. \& Leveritt, M. (2014) Australian practice nurses' perceptions of their role and competency to provide nutrition care to patients living with chronic disease.Australian Journal of Primary Health, 20(2), 203-208.

Cheung, S.T. (2003) The effects of chocolates given by patients on the well-being of nurses and their support staff. Nutrition and Health, 17(1), 65-69.

Creswell, J.W. (2007) Qualitative inquiry and research design: Choosing among five approaches Sage, Thousand Oaks, CA

Critical Appraisal Skills Programme (CASP) (2006) Qualitative research: appraisal tool. Public Health Resource Unit, Oxford.

Di Lorenzo, L., De Pergola, G., Zocchetti, C., L'Abbate, N., Basso, A., Pannacciulli, N., Cignarelli, M., Giorgino, R. \& Soleo, L. (2003) Effect of shift work on body mass index: results of a study performed in 319 glucose-tolerant men working in a Southern Italian industry. International Journal Of Obesity And Related Metabolic Disorders: Journal Of The International Association For The Study Of Obesity, 27(11), 1353-1358.

Engbers L, Van Poppel., Chin A Paw., \& van Mechelen, W. (2006) The effects of a controlled worksite environmental intervention on determinants of dietary behavior and selfreported fruit, vegetable and fat intake. BMC Public Health, 6, 253-253. 
Engbers, L.H., van Poppel, M.N.M., Chin A Paw, M.J.M. \& van Mechelen, W. (2005) Worksite health promotion programs with environmental changes: a systematic review. American Journal of Preventive Medicine, 29(1), 61-70.

Faugier, J., Lancaster, J., Pickles, D. \&Dobson, K. (2001a) Barriers to healthy eating in the nursing profession: part 1. Nursing Standard, 15(36), 33-6.

Faugier, J., Lancaster, J., Pickles, D. \& Dobson, K. (2001b) Barriers to healthy eating in the nursing profession: part 2. Nursing Standard, 15(37), 33-35 3p.

Fernandes, J., Portela, L., Rotenberg, L. \& Griep, R. (2013) Working hours and health behaviour among nurses at public hospitals. Revista Latino-Americana de Enfermagem (RLAE), 21(5), 1104-1111 8p.

French, S.A., Jeffery, R.W., Story, M., Breitlow, K.K., Baxter, J.S., Hannan, P. \& Snyder, M.P. (2001) Pricing and promotion effects on low-fat vending snack purchases: The CHIPS Study. American Journal of Public Health, 91(1), 112-117

Geliebter, A., Gluck, M.E., Tanowitz, M., Aronoff, N.J. \& Zammit, G.K. (2000) Work-shift period and weight change. Nutrition, 16(1), 27-29.

Glasziou, P., Irwig, L., Bain, C. \& Colditz, G. (2001) Systematic reviews in health care: a practical guide, Cambridge University Press.

Goetzel, R.Z. \& Ozminkowski, R.J. (2008) The health and cost benefits of work site healthpromotion programs. Annual Review of Public Health, 29(1), 303-323.

Groene, O. \& Jorgensen, S.J. (2005) Health promotion in hospitals-a strategy to improve quality in health care. The European Journal of Public Health, 15(1), 6-8.

Han, K., Trinkoff, A., Storr, C. \& Geiger-Brown, J. (2011) Job stress and work schedules in relation to nurse obesity. Journal of Nursing Administration, 41(11), 488-495.

Han, K., Trinkoff, A.M., Storr, C.L., Geiger-Brown, J., Johnson, K.L. \& Park, S. (2012) Comparison of job stress and obesity in nurses with favorable and unfavorable work schedules. Journal of Occupational and Environmental Medicine, 54(8), 928-932.

Han, K., Choi-Kwon, S. \& Kim, K.S. (2016) Poor dietary behaviors among hospital nurses in Seoul, South Korea. Applied Nursing Research: ANR, 30, 38-44.

Huth, J., Eliades, A., Handwork, C., Englehart, J. \& Messenger, J. (2013) Shift worked, quality of sleep and elevated body mass index in pediatric nurses. Journal of Pediatric Nursing, 28(6), e64-e73.

Jinks, A.M., Lawson, V. \& Daniels, R. (2003) A survey of the health needs of hospital staff: implications for health care managers. Journal of Nursing Management, 11(5), 343-350.

Johnson, A. \& Baum, F. (2001) Health promoting hospitals: a typology of different organizational approaches to health promotion. Health Promotion International, 16(3), 281 287.

Kim, M.J., Son, K.H., Park, H.Y., Choi, D.J., Yoon, C.H., Lee, H.Y., Cho, E.Y. \& Cho, M.C. (2013) Association between shift work and obesity among female nurses: Korean Nurses' Survey. BMC Public Health, 13, 1204.

King, K.A., Vidourek, R. \& Schwiebert, M. (2009) Disordered eating and job stress among nurses. Journal of Nursing Management, 17(7), 861-869.

Kirk, S., Cockbain, A. \& Beazley, J. (2008) Obesity in Tonga: A cross-sectional comparative study of perceptions of body size and beliefs about obesity in lay people and nurses. Obesity Research \& Clinical Practice, 2(1), 35-41.

Kivimaki, M., Kuisma, P., Virtanen, M. \& Elovainio, M. (2001) Does shift work lead to poorer health habits? A comparison between women who had always done shift work with those who had never done shift work. Work \& Stress, 15(1), 3-13.

Kouvonen, A., Kivimäki, M., Cox, S.J., Cox, T. \& Vahtera, J. (2005) Relationship between work stress and body mass index among 45,810 female and male employees. Psychosomatic Medicine, 67(4), 577-583. 
Kristal, A.R., Patterson, R.E., Glanz, K., Heimendinger, J., Hebert, J.R., Feng, Z. \& Probart, C. (1995) Psychosocial correlates of healthful diets: baseline results from the Working Well Study. Preventive Medicine, 24(3), 221-228.

Kyle, R.G., Neall, R.A. \& Atherton, I.M. (2016) Prevalence of overweight and obesity among nurses in Scotland: A cross-sectional study using the Scottish Health Survey. International Journal of Nursing Studies, 53, 126-133.

Lowden, A., Moreno, C., Holmbäck, U., Lennernäs, M. \& Tucker, P. (2010) Eating and shift work-effects on habits, metabolism and performance. Scandinavian Journal of Work, Environment \& Health, 150-162.

Malik, S., Blake, H. \& Batt, M. (2011) How healthy are our nurses? New and registered nurses compared. British Journal of Nursing, 20(8), 489-496.

Miles, M. \& Huberman, M. (1994) Qualitative Data Analysis: A Sourcebook of New Methods, Sage Publications, Beverly Hill, CA.

Miller, S., Alpert, P. \& Cross, C. (2008) Overweight and obesity in nurses, advanced practice nurses and nurse educators. Journal of the American Academy of Nurse Practitioners, 20(5), 25965.

Moher, D., Liberati, A., Tetzlaff, J., Altman, D.G. The PRISMA Group (2009) Preferred Reporting Items for Systematic Reviews and Meta-Analyses: The PRISMA Statement. PLoS Medicine 6(7).

Naghashpour, M., Amani, R., Nematpour, S. \& Haghighizadeh, M.H. (2013) Dietary, Anthropometric, Biochemical and Psychiatric Indices in Shift Work Nurses. Food and Nutrition Sciences, 4(12), 1239

Nahm, E., Warren, J., Zhu, S., An, M. \& Brown, J. (2012) Nurses' self-care behaviors related to weight and stress. Nursing Outlook, 60(5), e23-e31.

Ogunjimi, L., Ikorok, M.M. \& Olayinka, Y. (2010) Prevalence of obesity among Nigerian nurses: the Akwa Ibom State experience. International NGO Journal, 5(2), 45-49

Parker, W., Steyn, N., Levitt, N. \& Lombard, C. (2011) They think they know but do they? Misalignment of perceptions of lifestyle modification knowledge among health professionals. Public Health Nutrition, 14(8), 1429-38.

Perry, L., Gallagher, R. \& Duffield, C. (2015) The health and health behaviours of Australian metropolitan nurses: an exploratory study. BMC Nursing, 14.

Perry, L., Gallagher, R., Duffield, C., Sibbritt, D., Bichel-Findlay, J. \& Nicholls, R. (2016) Does nurses' health affect their intention to remain in their current position? Journal of Nursing Management DOI: 10.1111/jonm.12412.

Persson, M. \& Martensson, J. (2006) Situations influencing habits in diet and exercise among nurses working night shift. Journal of Nursing Management, 14(5), 414-423.

Phiri, L.P., Draper, C.E., Lambert, E.V. \& Kolbe-Alexander, T.L. (2014) Nurses' lifestyle behaviours, health priorities and barriers to living a healthy lifestyle: a qualitative descriptive study. BMC Nursing, 13.

QSR International Pty Ltd (2012) NVivo qualitative data analysis software. Version 10.

Ratner, P.A. \& Sawatzky, R. (2009) Health status, preventive behaviour and risk factors among female nurses. Health Rep, 20(3), 53-61.

Reeves, S., Newling-Ward, E. \& Gissane, C. (2004) The effect of shift-work on food intake and eating habits. Nutrition \& Food Science, 34(5), 216-221.

Sahu, S. \& Dey, M. (2011) Changes in food intake pattern of nurses working in rapidly rotating shift. Al Ameen Journal of Medical Sciences, 4(1), 14-22.

Smith, P., Fritschi, L., Reid, A. \& Mustard, C. (2013) The relationship between shift work and body mass index among Canadian nurses. Applied Nursing Research, 26(1), 24-31.

Sorensen, G., Stoddard, A.M., Dubowitz, T., Barbeau, E.M., Bigby, J., Emmons, K.M., Berkman, L.F. \& Peterson, K.E. (2007) The influence of social context on changes in fruit and 
vegetable consumption: results of the healthy directions studies. American Journal of Public Health, 97(7), 1216-1227.

Stokols, D. (1996) Translating social ecological theory into guidelines for community health promotion. American Journal of Health Promotion, 10(4), 282-298

Tada, Y., Kawano, Y., Maeda, I., Yoshizaki, T., Sunami, A., Yokoyama, Y., Matsumoto, H., Hida, A., Komatsu, T. \& Togo, F. (2014) Association of Body Mass Index with lifestyle and rotating shift work in Japanese female nurses. Obesity, 22(12), 2489-2493.

The World Bank (2016) World Bank country and lending groups: country classification. The World Bank. Washington D.C.

Yoshizaki, T., Tada, Y., Kodama, T., Mori, K., Kokubo, Y., Hida, A., Mitani, K., Komatsu, T., Togo, F. \& Kawano, Y. (2010) Influence of shiftwork on association between body mass index and lifestyle or dietary habits in female nurses and caregivers. Journal of Japanese Society of Nutrition and Food Science, 63(4), 161-167.

Tucker, S.J., Harris, M.R., Pipe, T.B. \& Stevens, S.R. (2010) Nurses' ratings of their health and professional work environments. AAOHN Journal, 58(6), 253-267.

Waterhouse, J., Buckley, P., Edwards, B. \& Reilly, T. (2003) Measurement of and some reasons for, differences in eating habits between night and day workers. Chronobiology International, 20(6), 1075-1092.

Whitehead, D. (2006) Workplace health promotion: the role and responsibility of health care managers. Journal of Nursing Management, 14(1), 59-68.

Whittemore, R. \& Knafl, K. (2005) The integrative review: updated methodology. Journal of Advanced Nursing, 52(5), 546-553.

Wong, H., Wong, M., Wong, S. \& Lee, A. (2010) The association between shift duty and abnormal eating behavior among nurses working in a major hospital: A cross-sectional study. International Journal of Nursing Studies, 47(8), 1021.

World Health Organization (1986) The Ottawa Charter for Health Promotion. WHO, Geneva, Switzerland

World Health Organisation (1991) Budapest Declaration on Health Promoting Hospitals, WHO, Copenhagen.

World Health Organisation (2015) Obesity and Overweight. WHO and European Office for Integrated Health Care Services.

Zapka, J.M., Lemon, S.C., Magner, R.P. \& Hale, J. (2009) Lifestyle behaviours and weight among hospital-based nurses. Journal of Nursing Management, 17(7), 853-860.

Zhao, I., Bogossian, F., Song, S., Turner, C. \& Dip, G. (2011) The association between shift work and unhealthy weight: A cross-sectional analysis from the Nurses and Midwives' ecohort study. Journal of Occupational and Environmental Medicine, 53(2), 153-158.

Zhao, I., Bogossian, F. \& Turner, C. (2012a) A cross-sectional analysis of the association between night-only or rotating shift work and overweight/obesity among female nurses and midwives. Journal of Occupational and Environmental Medicine,54(7), 834-840.

Zhao, I., Bogossian, F. \& Turner, C. (2012b) Does maintaining or changing shift types affect BMI? A longitudinal study. Journal of Occupational and Environmental Medicine, 54(5), 525531.

Zhao, I. \& Turner, C. (2008) The impact of shift work on people's daily health habits and adverse health outcomes. Australian Journal of Advanced Nursing, 25(3), 8-22 15p.

Zhu, D., Norman, I.J. \& While, A.E. (2014) Nurses' misperceptions of weight status associated with their body weight, demographics and health status. Public Health Nutrition, 17(3), 56978. 
FIGURE 1: Guidelines for healthy eating for nurses (Adapted from Lowden et al. 2010)

Adhere to a normal day and night pattern of food intake which is rich in fruit, vegetables, pulses, whole grains and nuts

Eat a variety of food choices: 'complete' meals (animal foods and/or protein rich vegetable foods + non-starchy vegetables and fruits) or vegetarian meals and 'high quality' snacks (from complete and/or vegetarian food groups)

Avoid foods and beverages classified as 'low quality snacks' (alcohol or food products with added sugar)

Avoid an over-reliance on (high-energy content) convenience foods and high-carbohydrate foods and avoid sugar-rich products and non-fibre carbohydrate foods

Maintain regular meal times

Divide the 24-intake in to eating events with three satiating meals

Avoid or restrict eating between midnight and 6am; eat at the beginning and end of each shift and avoid eating large meals ( $>20 \%$ of daily energy intake) before sleep

Allow adequate time between shifts for meal preparation and sleep

Maintain a healthy lifestyle when not working (exercise, regular meal times, good sleep hygiene) 
FIGURE 2: PRISMA flow chart of the systematic review process (Moher et al. 2009)

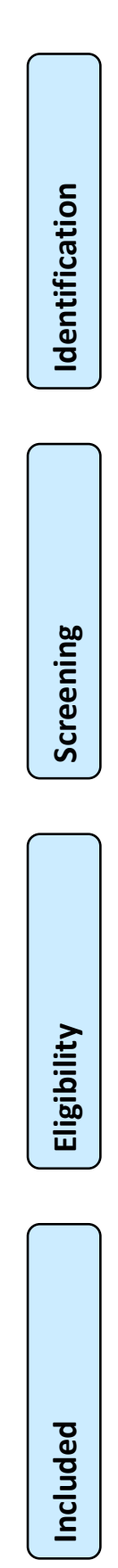

Additional records identified through other sources

( $n=1735)$

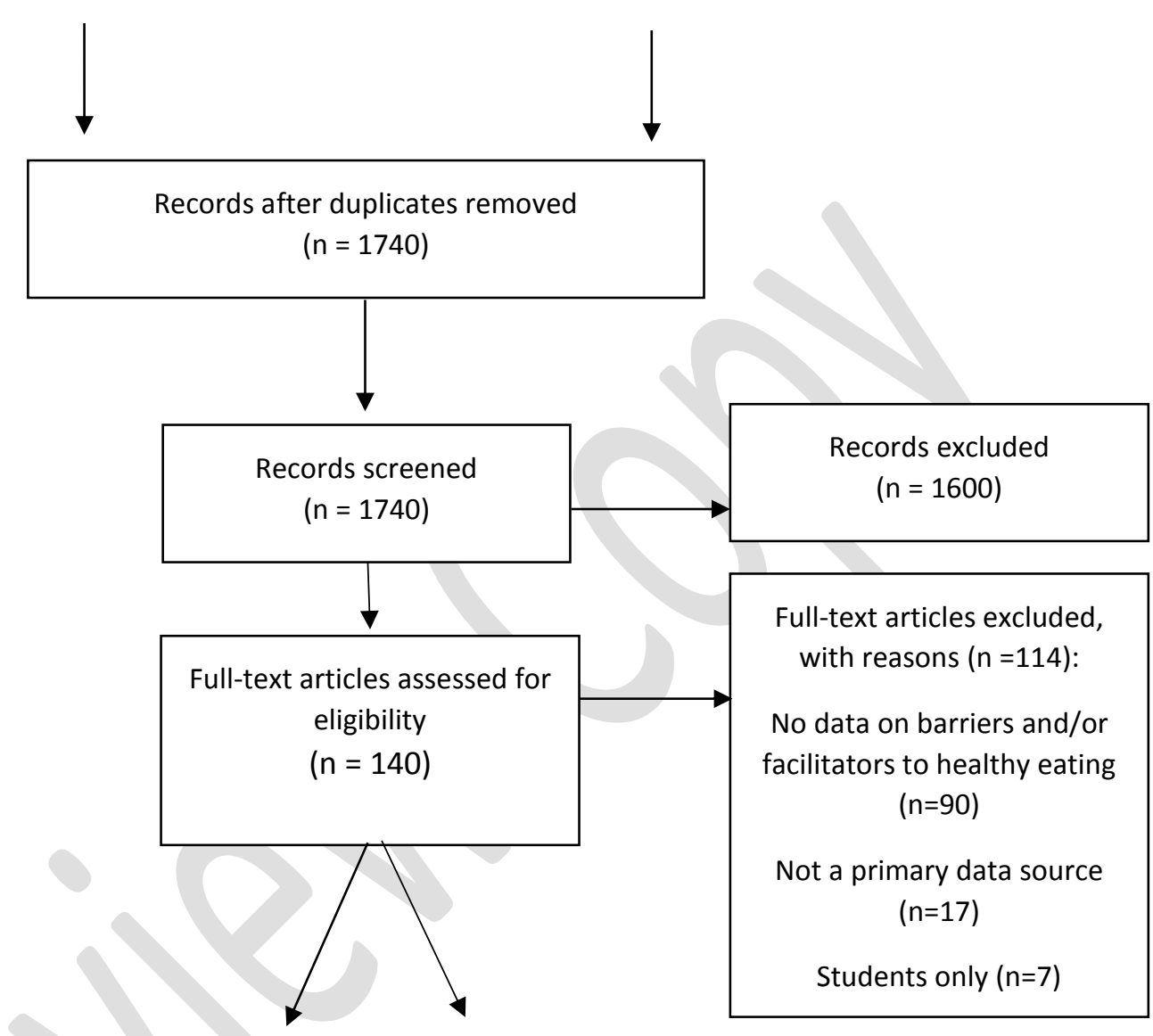

Studies included in quantitative synthesis $(n=21)$
Studies included in qualitative synthesis $(n=5)$ 
SUPPLEMENTARY TABLE 1: Search strategy

\begin{tabular}{|l|l|l|}
\hline Database 2000-2016 & Search terms & Papers retrieved \\
\hline $\begin{array}{l}\text { PROQUEST HEALTH } \\
\text { \& MEDICINE }\end{array}$ & $\begin{array}{l}\text { Nurs* (Title) AND (Healthy eating OR nutrition OR diet) AND } \\
\text { (Occupational health OR shift work OR workplace) AND } \\
\text { (barrier OR facilitat*) }\end{array}$ & 1151 \\
\hline SCIENCEDIRECT & $\begin{array}{l}\text { Nurs* (Title) AND (Healthy eating OR nutrition OR diet) AND } \\
\text { (Occupational health OR shift work OR workplace) AND } \\
\text { (barrier OR facilitat*) }\end{array}$ & 140 \\
\hline MEDLINE & $\begin{array}{l}\text { Nurs* AND (Healthy eating OR nutrition OR diet) AND } \\
\text { (Occupational health OR Occupational medicine OR shift work } \\
\text { OR workplace) AND (barrier OR facilitat*) }\end{array}$ & 185 \\
\hline CINAHL & $\begin{array}{l}\text { Nurs* AND (Healthy eating OR nutrition OR diet) AND } \\
\text { (Occupational health OR shift work) AND (barrier OR } \\
\text { facilitat*) }\end{array}$ & 167 \\
\hline PsycINFO & $\begin{array}{l}\text { Nurs* AND (Healthy eating OR nutrition OR diet) AND } \\
\text { (Occupational health OR shift work OR workplace) AND } \\
\text { (barrier OR facilitat*) }\end{array}$ & 92 \\
\hline Hand search & \multicolumn{1}{|l}{} & 16 \\
\hline
\end{tabular}


SUPPLEMENTARY TABLE 2: Studies included in the review

\begin{tabular}{|c|c|c|c|c|}
\hline Author(s) & Design & Setting \& country & Participants & Data collection method \\
\hline Aranda et al. 2014 & Qualitative & U.K; primary care settings & $\mathrm{N}=7$ female $\mathrm{RNs}$ & Interviews \\
\hline Blake et al. 2014 & Cross-sectional & U.K; acute hospital & $\mathrm{N}=67$ pediatric nurses ( $88 \%$ female) & Questionnaire \\
\hline Brown et al. 2007 & $\begin{array}{l}\text { Cross-sectional } \\
\text { correlational }\end{array}$ & U.K; 4 primary care settings & $\mathrm{N}=298 \mathrm{DNs}, \mathrm{N}=119 \mathrm{HVs}, \mathrm{N}=147 \mathrm{PNs}$ & Questionnaire \\
\hline Cass et al. 2014 & Qualitative & Australia; primary care & $\mathrm{N}=20$ female $\mathrm{PNs}$ & Semi-structured interviews \\
\hline Cheung, 2003 & Cross sectional & UK; 2 Hospitals & $\begin{array}{l}\mathrm{N}=128(\mathrm{~N}=89 \text { nurses, } \mathrm{N}=21 \text { WAs, } \\
\mathrm{N}=18 \text { nursing students })\end{array}$ & Questionnaire \\
\hline Faugier et al. 2001a & Cross sectional & UK; 8 healthcare sites & $\mathrm{N}=126$ nurses & Questionnaire \\
\hline Faugier et al. 2001b & $\begin{array}{l}\text { Qualitative unstructured } \\
\text { interviews, observation }\end{array}$ & $\begin{array}{l}\text { UK; } 6 \text { acute hospitals, } 1 \\
\text { NHS walk-in centre, } 1 \text { NHS } \\
\text { Direct site }\end{array}$ & $\mathrm{N}=24$ nurses $(\mathrm{x} 3$ each site $)$ & $\begin{array}{l}\text { Observations of catering } \\
\text { facilities, interviews }\end{array}$ \\
\hline Fernandes et al. 2013 & $\begin{array}{l}\text { Analysis of cross sectional } \\
\text { data }\end{array}$ & $\begin{array}{l}\text { Rio, Brazil; } 18 \text { public } \\
\text { hospitals }\end{array}$ & $\begin{array}{l}\mathrm{N}=2,279 \text { nurses }(87.3 \% \text { women, } \\
12.7 \% \text { male })\end{array}$ & Questionnaire \\
\hline Geliebter et al. 2000 & Cross sectional & USA; hospital & $\begin{array}{l}\mathrm{N}=85 \text { shift workers (nurses, NAs \& } \\
\text { security personnel) }\end{array}$ & Questionnaire \\
\hline Han et al. 2011 & $\begin{array}{l}\text { Secondary data analysis - } \\
\text { cross sectional longitudinal } \\
\text { survey }\end{array}$ & 2 US states & $\mathrm{N}=2103$ female nurses & Questionnaire \\
\hline Han et al. 2012 & $\begin{array}{l}\text { Correlational cross- } \\
\text { sectional analysis of } \\
\text { longitudinal study }\end{array}$ & $\begin{array}{l}2 \text { states USA; various health } \\
\text { facilities }\end{array}$ & $\mathrm{N}=2624$ female nurses & Questionnaire \\
\hline Jinks et al. 2003 & Cross-sectional & Wales; Hospitals & $\begin{array}{l}\mathrm{N}=1021 \text { hospital staff }(\mathrm{N}=490,48 \% \\
\text { nurses), } 85 \% \text { female }\end{array}$ & Questionnaire \\
\hline King et al.2009 & Cross-sectional & Ohio, USA; Health facilities, & $\begin{array}{l}\mathrm{N}=435 \text { RN's \& LPNs }(\mathrm{N}=414 \text { female, } \\
\mathrm{N}=19 \text { male) }\end{array}$ & Questionnaire \\
\hline Kirk et al. 2008 & $\begin{array}{l}\text { Cross-sectional } \\
\text { comparative }\end{array}$ & Tonga; hospital & $\begin{array}{l}\mathrm{N}=73 \text { lay public }(\mathrm{N}=31 \text { males, } \mathrm{N}=42 \\
\text { females) \& } \mathrm{N}=34 \text { nurses }(\mathrm{N}=9 \text { males, } \\
\mathrm{N}=25 \text { females })\end{array}$ & Questionnaire \\
\hline Miller et al. 2008 & Cross-sectional & $\begin{array}{l}6 \text { US states; variety of } \\
\text { healthcare settings }\end{array}$ & $\begin{array}{l}\mathrm{N}=760 \text { nurses }(72 \% \mathrm{RNs}, 15 \% \\
\text { advanced practice, } 5 \% \text { nursing } \\
\text { professor/instructor), } 92 \% \text { female }\end{array}$ & Questionnaire \\
\hline
\end{tabular}




\begin{tabular}{|c|c|c|c|c|}
\hline Naghashpour et al. 2013 & $\begin{array}{l}\text { Cross sectional } \\
\text { comparative }\end{array}$ & Iran; 6 hospitals & $\begin{array}{l}\mathrm{N}=55 \text {-day time nurses, } \mathrm{N}=43 \text {-shift } \\
\text { nurses (working outside of 8:00 am to } \\
\text { 2:00 pm) }\end{array}$ & Questionnaire \\
\hline Nahm et al. 2012 & Cross sectional & $\begin{array}{l}\text { USA; Urban teaching } \\
\text { hospital }\end{array}$ & $\mathrm{N}=169$ nurses & Questionnaire \\
\hline Parker, 2011 & $\begin{array}{l}\text { Comparative cross- } \\
\text { sectional }\end{array}$ & $\begin{array}{l}\text { Cape town, South Africa: } 30 \\
\text { public health facilities, } 4 \\
\text { tertiary institutions }\end{array}$ & $\begin{array}{l}\mathrm{N}=223,(\mathrm{~N}=61 \text { doctors, } \mathrm{N}=149 \text { nurses, } \\
\mathrm{N}=13 \text { health promoters })\end{array}$ & Questionnaire \\
\hline Persson et al. 2006 & Qualitative descriptive & $\begin{array}{l}\text { Sweden; municipality health } \\
\text { facilities/home visiting }\end{array}$ & $\begin{array}{l}\mathrm{N}=27(\mathrm{~N}=2 \mathrm{RNs}, \mathrm{N}=25 \mathrm{EN}) \text { working } \\
\text { nights }\end{array}$ & $\begin{array}{l}\text { Critical Incident Technique } \\
\text { Semi-structured Interviews }\end{array}$ \\
\hline Phiri et al. 2014 & Qualitative & $\begin{array}{l}\text { South Africa; } 5 \text { public } \\
\text { hospitals ( } 3 \text { District, } 1 \\
\text { specialist, } 1 \text { TB hospital } \\
\end{array}$ & $\begin{array}{l}\mathrm{N}=102 \text { nurses (day shift } \mathrm{N}=36, \text { night } \\
\text { shift } \mathrm{N}=57 \text { ) \& management } \mathrm{N}=9 \text { ) }\end{array}$ & $\begin{array}{l}12 \text { focus groups, } 7 \text { key informant } \\
\text { interviews }\end{array}$ \\
\hline Sahu et al. 2011 & Cross sectional & $\begin{array}{l}\text { West Bengal, India, } \\
\text { Government hospitals }\end{array}$ & $\begin{array}{l}\mathrm{N}=40 \text { nurses rotating shifts, } \mathrm{n}=35 \\
\text { general duty }\end{array}$ & Questionnaire \\
\hline Smith et al. 2013 & $\begin{array}{l}\text { Analysis of cross sectional } \\
\text { survey data }\end{array}$ & $\begin{array}{l}\text { Canada; hospital \& long- } \\
\text { term care facility }\end{array}$ & $\mathrm{N}=8665$ nurses & Questionnaire \\
\hline Waterhouse, 2003 & Cross sectional & UK; Hospitals, university & $\begin{array}{l}\mathrm{N}=50 \text { day working university staff, } \\
\mathrm{N}=43 \text { night nurses }(20: 00-06: 00 \mathrm{~h})\end{array}$ & Questionnaire \\
\hline Wong et al. 2010 & Cross sectional & $\begin{array}{l}\text { Hong Kong; major acute } \\
\text { hospital }\end{array}$ & $\mathrm{N}=378$ nurses & Questionnaire \\
\hline Zapka et al. 2009 & Cross-sectional & USA; 6 hospitals & $\mathrm{N}=194$ nurses & Questionnaire \\
\hline Zhu et al. 2014 & Cross sectional & London; University & $\begin{array}{l}\mathrm{N}=355 \text { student nurses, } \mathrm{N}=409 \\
\text { qualified nurses }\end{array}$ & Questionnaire \\
\hline
\end{tabular}

Abbreviations: RNs: Registered nurses, ENs: Enrolled nurses, DNs: District Nurses, PNs: Practice Nurses, LPNs: Licenced practical nurse, NAs: Nurse Aides, WAs: Ward assistants, HVs: Health visitors, TB: Tuberculosis 
SUPPLEMENTARY TABLE 3: Quality criteria-quantitative studies (adapted from Glasziou et al. 2001)

\begin{tabular}{|c|c|c|c|c|c|c|c|c|c|c|c|c|}
\hline $\begin{array}{l}\text { Quality criteria: } \\
\text { quantitative studies }\end{array}$ & $\begin{array}{l}\text { Geliebter } \\
\text { et al. } 2000\end{array}$ & $\begin{array}{l}\text { Faugier } \\
\text { et al. } \\
2001 \mathrm{a}\end{array}$ & $\begin{array}{l}\text { Jinks et } \\
\text { al. } \\
2003\end{array}$ & $\begin{array}{l}\text { Cheung, } \\
2003\end{array}$ & $\begin{array}{l}\text { Waterhouse } \\
2003\end{array}$ & $\begin{array}{l}\text { Brown et } \\
\text { al. } 2007\end{array}$ & $\begin{array}{l}\text { Kirk et } \\
\text { al. } 2008\end{array}$ & $\begin{array}{l}\text { Miller } \\
\text { et al. } \\
2008\end{array}$ & $\begin{array}{l}\text { King et } \\
\text { al.2009 }\end{array}$ & $\begin{array}{l}\text { Zapka et } \\
\text { al. } 2009\end{array}$ & $\begin{array}{l}\text { Wong } \\
\text { et al. } \\
2010\end{array}$ & $\begin{array}{l}\text { Parker, } \\
2011\end{array}$ \\
\hline \multicolumn{13}{|l|}{ Minimising selection bias: } \\
\hline $\begin{array}{l}\text { 1. Study participants well } \\
\text { defined (time, place, and } \\
\text { personal characteristics)? }\end{array}$ & $\mathrm{Y}$ & $\mathrm{Y}$ & $\mathrm{Y}$ & $\mathrm{N}$ & $\mathrm{Y}$ & $\mathrm{Y}$ & $\mathrm{Y}$ & $\mathrm{Y}$ & $\mathrm{Y}$ & $\mathrm{Y}$ & $\mathrm{Y}$ & $\mathrm{Y}$ \\
\hline $\begin{array}{l}\text { 2. Selection random or } \\
\text { consecutive? }\end{array}$ & $\mathrm{N}$ & $\mathrm{N}$ & $\mathrm{N}$ & $\mathrm{U}$ & $\mathrm{N}$ & $\mathrm{N}$ & $\mathrm{N}$ & $\mathrm{Y}$ & $\mathrm{Y}$ & $\mathrm{Y}$ & $\mathrm{N}$ & $\mathrm{N}$ \\
\hline 3.Participant rate $>60 \% \underline{\mathbf{O R}}$ & $\mathrm{N}$ & $\mathrm{N}$ & $\mathrm{N}$ & $\mathrm{U}$ & $\mathrm{U}$ & $\mathrm{Y}$ & $\mathrm{U}$ & $\mathrm{N}$ & $\mathrm{N}$ & $\mathrm{N}$ & $\mathrm{N}$ & $\mathrm{U}$ \\
\hline $\begin{array}{l}\text { If participant rate is low, } \\
\text { comparison respondents/ Non- } \\
\text { respondents described? }\end{array}$ & $\mathrm{N}$ & $\mathrm{N}$ & $\mathrm{N}$ & $\mathrm{N}$ & $\mathrm{N}$ & - & $\mathrm{N}$ & $\mathrm{N}$ & $\mathrm{N}$ & $\mathrm{Y}$ & $\mathrm{N}$ & $\mathrm{N}$ \\
\hline \multicolumn{13}{|l|}{$\begin{array}{l}\text { Minimising measurement } \\
\text { bias: }\end{array}$} \\
\hline $\begin{array}{l}\text { 4.Standardised/ validated } \\
\text { questionnaire } \underline{\mathbf{O R}}\end{array}$ & $\mathrm{N}$ & $\mathrm{N}$ & $\mathrm{N}$ & $\mathrm{N}$ & $\mathrm{N}$ & $\mathrm{N}$ & $\mathrm{Y} / \mathrm{N}$ & $\mathrm{U}$ & $\mathrm{Y}$ & $\mathrm{Y}$ & $\mathrm{Y}$ & $\mathrm{Y}$ \\
\hline $\begin{array}{l}\text { 5. Did the paper report ethical } \\
\text { review? } *\end{array}$ & $\mathrm{Y}$ & $\mathrm{N}$ & $\mathrm{N}$ & $\mathrm{N}$ & $\mathrm{Y}$ & $\mathrm{Y}$ & $\mathrm{Y}$ & $\mathrm{Y}$ & $\mathrm{Y}$ & $\mathrm{Y}$ & $\mathrm{Y}$ & $\mathrm{Y}$ \\
\hline
\end{tabular}

$\mathrm{Y}=\mathrm{yes}, \mathrm{N}=\mathrm{no}, \mathrm{U}=$ uncertain 
SUPPLEMENTARY TABLE 4: Methodological assessment of qualitative studies (Critical Appraisal Skills Programme: CASP, 2006)

\begin{tabular}{|l|c|c|c|c|c|}
\hline $\begin{array}{l}\text { Methodological assessment of qualitative } \\
\text { studies (CASP, 2006) }\end{array}$ & $\begin{array}{l}\text { Aranda \& } \\
\text { McGreevy } \\
2014\end{array}$ & $\begin{array}{l}\text { Cass } \text { et } \\
\text { al. } \\
2014\end{array}$ & $\begin{array}{l}\text { Faugier } \text { et } \\
\text { al. 2001b }\end{array}$ & $\begin{array}{l}\text { Phiri } \text { et } \\
\text { al. 2014 }\end{array}$ & $\begin{array}{l}\text { Persson } \text { et } \\
\text { al. 2006 }\end{array}$ \\
\hline Qualitative evaluation criteria & & & & & \\
\hline $\begin{array}{l}\text { Was there a clear statement of the aims of the } \\
\text { research? }\end{array}$ & $\mathrm{Y}$ & $\mathrm{Y}$ & $\mathrm{Y}$ & $\mathrm{Y}$ & $\mathrm{Y}$ \\
\hline Is a qualitative methodology appropriate? & $\mathrm{Y}$ & $\mathrm{Y}$ & $\mathrm{Y}$ & $\mathrm{Y}$ & $\mathrm{Y}$ \\
\hline $\begin{array}{l}\text { Was the research design appropriate to } \\
\text { address the aims of the research? }\end{array}$ & $\mathrm{Y}$ & $\mathrm{Y}$ & $\mathrm{Y}$ & $\mathrm{Y}$ & $\mathrm{Y}$ \\
\hline $\begin{array}{l}\text { Was the recruitment strategy appropriate to } \\
\text { the aims of the research? }\end{array}$ & $\mathrm{Y}$ & $\mathrm{Y}$ & $\mathrm{Y}$ & $\mathrm{Y}$ & $\mathrm{Y}$ \\
\hline $\begin{array}{l}\text { Was the data collected in a way that addressed } \\
\text { the research issue? }\end{array}$ & $\mathrm{Y}$ & $\mathrm{Y}$ & $\mathrm{N}$ & $\mathrm{Y}$ & $\mathrm{Y}$ \\
\hline $\begin{array}{l}\text { Has the relationship between researcher and } \\
\text { participants been adequately considered? }\end{array}$ & $\mathrm{N}$ & $\mathrm{N}$ & $\mathrm{N}$ & $\mathrm{N}$ & $\mathrm{N}$ \\
\hline $\begin{array}{l}\text { Have ethical issues been taken into } \\
\text { consideration? }\end{array}$ & $\mathrm{Y}$ & $\mathrm{Y}$ & $\mathrm{N}$ & $\mathrm{Y}$ & $\mathrm{Y}$ \\
\hline Was the data analysis sufficiently rigorous? & $\mathrm{Y}$ & $\mathrm{Y}$ & $\mathrm{U}$ & $\mathrm{Y}$ & $\mathrm{Y}$ \\
\hline Is there a clear statement of findings? & $\mathrm{Y}$ & $\mathrm{Y}$ & $\mathrm{U}$ & $\mathrm{Y}$ & $\mathrm{Y}$ \\
\hline How valuable is the research? & $\mathrm{Y}$ & $\mathrm{Y}$ & $\mathrm{Y}$ & $\mathrm{Y}$ & $\mathrm{Y}$ \\
\hline
\end{tabular}

$\mathrm{Y}=\mathrm{yes}, \mathrm{N}=\mathrm{no}, \mathrm{U}=$ uncertain 
SUPPLEMENTARY TABLE 5: Studies included in review: Barriers and facilitators to healthy eating

\begin{tabular}{|c|c|}
\hline Individual factors & Barriers and facilitators to healthy eating \\
\hline Aranda et al. 2014 & $\begin{array}{l}\text { Barriers: nurses identify struggles with body image, emotional eating, busy stressful life, time } \\
\text { constraints and working shifts as contributing to disordered eating }\end{array}$ \\
\hline Blake et al. 2014 & $\begin{array}{l}\text { Barriers: self-efficacy - nurses were more likely to undertake healthy behaviours themselves or be } \\
\text { confident in promoting health to others if they had higher self-efficacy, and were more likely to } \\
\text { consume recommended amounts of fruit and vegetables a day, than those with lower levels of self- } \\
\text { efficacy }\end{array}$ \\
\hline Brown et al. 2007 & $\begin{array}{l}\text { Barriers: nurses report limited training in obesity prevention and limited organizational support. Only } \\
8.7 \% \text { reported training or updates about obesity in the past } 5 \text { years }\end{array}$ \\
\hline Cass et al. 2014 & $\begin{array}{l}\text { Barriers: some inadequate nutrition knowledge and confidence was reported by nurses. Limited } \\
\text { nutrition content in curriculum and limited opportunities for continuing education. }\end{array}$ \\
\hline Jinks et al. 2003 & $\begin{array}{l}\text { Barriers: limited motivation: } 92 \% \text { reported it would be 'pretty tough' or 'almost impossible' to change } \\
\text { their current lifestyle habits. }\end{array}$ \\
\hline Kirk et al. 2008 & $\begin{array}{l}\text { Barriers: both nursing and lay groups underestimated their own body size: more pronounced in the lay } \\
\text { group: } 12 \text { of } 69 \text { lay respondents }(17.4 \%) \text { gave a self-reported weight classification that matched their } \\
\text { actual weight classification. } 15 \text { out of } 33 \text { nurses }(45.5 \%) \text { gave a self-reported weight classification that } \\
\text { matched their actual weight }\end{array}$ \\
\hline Miller et al. 2008 & $\begin{array}{l}\text { Barriers: } 53 \% \text { nurses overweight but lacked motivation to change diets/exercise habits, } 40 \% \text { of } \\
\text { OW/obese nurses indicated they ate a healthy diet and exercise regularly but were unable to lose } \\
\text { weight. } 62 \% \text { reported the need for continuing obesity education. }\end{array}$ \\
\hline Parker, 2011 & $\begin{array}{l}\text { Barrier: other than professional nurses, knowledge of lifestyle modification, including diet, was } \\
\text { mediocre. Approx. } 20 \% \text { rated their knowledge as excellent. }\end{array}$ \\
\hline Zapka et al. 2009 & $\begin{array}{l}\text { Barriers: nurses who perceived themselves as overweight reported fewer fruit and vegetable servings } \\
\text { than those who perceived themselves as just right or underweight. Those who strongly agreed that their } \\
\text { job is stressful reported significantly more servings of fruits and vegetables than those who disagreed } \\
\text { or were unsure about job stress. }\end{array}$ \\
\hline Zhu et al. 2014 & $\begin{array}{l}\text { Barriers: } 71.9 \%(\mathrm{~N}=470) \text { classified their weight status correctly, } 8.1 \%(\mathrm{~N}=53) \text { overestimating, and } \\
20 \%(\mathrm{~N}=131) \text { underestimated their weight status. Of those in overweight category by BMI, } 42.1 \% \\
(\mathrm{~N}=77) \text { identified themselves as normal weight, and those in the obese category by BMI, } 24.7 \% \\
(\mathrm{~N}=18) \text { accurately evaluated their weight status. Correct rate of perceived weight status no better than } \\
\text { lay population. }\end{array}$ \\
\hline
\end{tabular}




\begin{tabular}{|c|c|}
\hline Physical environment & \\
\hline Faugier et al. 2001a & $\begin{array}{l}\text { Barriers: high cost of healthy food, limited choice at night, inconvenient location of catering facilities, } \\
\text { limited nutrition knowledge. }\end{array}$ \\
\hline Faugier et al. 2001b & $\begin{array}{l}\text { Barriers: limited availability of healthy food options outside of traditional work hours, healthy } \\
\text { options not promoted in staff canteen, distance from catering facilities, hot food runs out, lack of water } \\
\text { dispensers, unappealing dehydrated food for night staff, expensive healthy food. } \\
\text { Enablers: healthy hospital canteens with: pleasant dining areas, menus with a wide selection of healthy } \\
\text { choices, vending machines with healthy choices, ready-made meals and sandwiches kept in chillers for } \\
\text { night shift workers, healthy food options indicated by healthy heart symbol, wards with fridges, } \\
\text { microwaves, water dispensers }\end{array}$ \\
\hline Nahm et al. 2012 & $\begin{array}{l}\text { Barrier: fresh fruits and salads were more expensive than fast foods in health facility cafeterias. } \\
\text { Cafeterias were closed at night. }\end{array}$ \\
\hline Phiri et al. 2014 & $\begin{array}{l}\text { Barriers: health facility cafeteria offered mainly unhealthy food (e.g. pies, hot chips) and healthy food } \\
\text { (e.g. fruit, salad) were more expensive. Cafeterias were closed at night. }\end{array}$ \\
\hline Smith et al. 2013 & $\begin{array}{l}\text { Barriers: of } \mathrm{N}=8665 \text { nurses working in hospitals or long-term care facilities, only } 10 \% \text { of those } \\
\text { working evening and } 8.7 \% \text { of mixed shift nurses reported healthy food was available during shifts } \\
\text { worked. } \\
\text { Enabler: } 15.1 \% \text { nurses working night shift reported healthy eating options were available during shift } \\
\text { worked. }\end{array}$ \\
\hline \multicolumn{2}{|l|}{ Organisational } \\
\hline Faugier et al. 2001a,b & $\begin{array}{l}\text { Barriers: unsupportive employer, shift patterns, lack of/shorter breaks, high workload, low staffing } \\
\text { levels/high workloads meant less frequent breaks }\end{array}$ \\
\hline Fernandes et al. 2013 & $\begin{array}{l}\text { Barriers: an association between high consumption of fried food and long work hours in women - } \\
\text { reverse in male nurses. Female nurses worked longer total work hours than male (domestic }+ \\
\text { professional hours). }\end{array}$ \\
\hline Geliebter et al. 2000 & $\begin{array}{l}\text { Barriers: late shift group gained more weight (mean } 4.3 \mathrm{~kg} \text { ) than day shift group (mean } 0.9 \mathrm{~kg}, \mathrm{P}=0.02 \text { ). } \\
\text { Late shift workers exercised less, increased their food intake, but ate fewer meals than day workers. }\end{array}$ \\
\hline Han et al. 2012 & $\begin{array}{l}\text { Barriers: among nurses with unfavourable work schedules, healthy behaviours (exercise, sleep) were } \\
\text { inversely associated with obesity. Among those with favourable work schedules, obese nurses reported } \\
\text { significantly more unhealthy behaviours (smoking, alcohol use; odds ratio [OR], } 1.19 ; 95 \% \text { confidence } \\
\text { interval [CI], 1.02-1.38) and less management support at work (OR, 0.83; 95\% CI, 0.68-0.99). } \\
\text { Schedules and limited support may mean less time and energy to access/eat healthy food, few } \\
\text { opportunities to engage in physical activity and may result in stress induced eating. }\end{array}$ \\
\hline
\end{tabular}




\begin{tabular}{|c|c|}
\hline Han et al. 2011 & $\begin{array}{l}\text { Barriers: long work hours were significantly associated with being overweight/obese }-(\mathrm{OR}=1.23 \text {, } \\
95 \% \mathrm{CI}=1.08-1.40 \mathrm{P}<.01) \text {. No significant findings related to job stress and weight status. }\end{array}$ \\
\hline King et al. 2009 & $\begin{array}{l}\text { Barriers: nurses with high levels of perceived job stress and low levels of body satisfaction had higher } \\
\text { disordered eating: frequently or always eating when stressed (33.0\%), bored (34.1\%) and upset } \\
(31.4 \%) \text {. Nurses reported thinking about or reaching for food when bored (30.4\%) or stressed }(29.1 \%) \text {. }\end{array}$ \\
\hline Naghashpour et al. 2013 & $\begin{array}{l}\text { Barriers: shift working outside of daylight hours/at weekend is associated with lower dietary intakes } \\
\text { of some B vitamins, magnesium and iron }(p<0.05) \text {. No difference in anthropometric variables } \\
\text { between day and night/evening shift workers }\end{array}$ \\
\hline Nahm et al. 2012 & $\begin{array}{l}\text { Barriers: } 53.8 \%, \mathrm{~N}=91 \text { had an irregular meal pattern, mostly because they were too busy }(\mathrm{N}=41) \text {. BMI } \\
\text { had a significant inverse relationship with having a regular meal schedule. Participants who reported } \\
\text { greater stress had more irregular meal schedules. The most frequently used stress-release method was } \\
\text { eating }(\mathrm{N}=32) \text {, followed by exercise }(\mathrm{N}=31)\end{array}$ \\
\hline Persson et al. 2006 & $\begin{array}{l}\text { Barriers: night staff reported they ate unhealthy food to stay awake and satisfy craving; sweet/junk } \\
\text { food was an easier option at night; high demands at work contributed to stress, which led to unhealthy } \\
\text { eating habits. }\end{array}$ \\
\hline Phiri et al. 2014 & $\begin{array}{l}\text { Barriers: nurses had lack of time to prepare healthy meals due to tiredness and long working hours. } \\
\text { They identified eating and drinking unhealthy high calorie food and drink as a way of coping with } \\
\text { work demands and to reduce fatigue. }\end{array}$ \\
\hline Sahu et al. 2011 & $\begin{array}{l}\text { Barriers: in night shift workers, the number of full meals per } 24 \text { hour, appetite and eating satisfaction } \\
\text { were significantly lower }(p<0.0005) \text { and the number of snacks were significantly higher }(\mathrm{p}<0.0005) \\
\text { than other shifts and general duty nurses. }\end{array}$ \\
\hline Smith et al. 2013 & $\begin{array}{l}\text { Barriers: at work, } 9.3 \% \text { reported healthy food is available during shifts worked, } 49.6 \% \text { reported health } \\
\text { food available but not during shifts worked. }\end{array}$ \\
\hline Waterhouse, 2003 & $\begin{array}{l}\text { Barriers: hospital canteen closed at } 2.30 \mathrm{am} \text {; offered limited choice of cooked food; vending machines } \\
\text { available selling junk food and soft drinks. Night workers ate a higher intake of snacks and lower } \\
\text { intake of hot meals. General decrease in and appreciation of food at night. }\end{array}$ \\
\hline Wong et al. 2010 & $\begin{array}{l}\text { Barriers: shift duties were positively associated with abnormal eating behaviour among hospital } \\
\text { nurses. Nurses having } 4 \text { or more shift duties per month were more likely to present with abnormal } \\
\text { emotional (adjusted odds ratio aOR } 2.91,95 \% \text { C.I. } 1.57-5.42, p=0.001 \text { ) and restraint (aOR } 3.35,95 \% \\
\text { C.I. } 1.76-6.38, p<0.001 \text { ) Dutch Eating Behaviour (DEBQ) scores. }\end{array}$ \\
\hline Social re & \\
\hline
\end{tabular}




\begin{tabular}{|l|l|}
\hline Cheung, 2003 & $\begin{array}{l}\text { Barriers: on average 5.4 patient-given chocolates were eaten each day. The most common reason } \\
\text { given by health staff for eating them was simply 'because they were there'. }\end{array}$ \\
\hline Persson et al. 2006 & $\begin{array}{l}\text { Barriers: } 93 \text { work situations with a negative influence on diet and exercise activities, many of which } \\
\text { were social factors e.g. nurses influenced each other in choosing unhealthy food, craving for junk food } \\
\text { when others eating it, share a 'treat' meal on special occasions etc. } \\
\text { Enablers: } 50 \text { work related situations with a positive influence on diet and exercise habits e.g. } \\
\text { colleagues influenced others with healthy eating behaviours, working nights provided flexibility to } \\
\text { exercise with others who were free during the day, healthy eating was influenced by education sessions } \\
\text { at work. }\end{array}$ \\
\hline Phiri et al. 2014 & $\begin{array}{l}\text { Barriers: some nurses felt that their colleagues negatively influenced their health behaviours by } \\
\text { making them feel guilty for choosing not to eat cake. } \\
\text { Enablers: some nurses felt that their colleagues were a good influence and encouraged them to have a } \\
\text { healthy diet and also gave advice on healthy food choices. }\end{array}$ \\
\hline
\end{tabular}


SUPPLEMENTARY TABLE 6: thematic analysis coding structure

\begin{tabular}{|c|c|c|c|}
\hline Overarching themes & Key Themes & Sub-themes - barriers & Sub-themes - facilitators \\
\hline Organisational features & $\begin{array}{ll}- & \text { Unfavourable work schedules } \\
\text { - } & \text { Long working hours } \\
\text { - } & \text { Shift work } \\
\text { - } & \text { High workload } \\
\text { - } & \text { Short/few work breaks } \\
\text { - } & \text { Domestic demands }\end{array}$ & $\begin{array}{ll}\text { - } & \text { Craving unhealthy food due to fatigue } \\
\text { - } & \text { Little time to take care of yourself } \\
\text { - } & \text { Changes in normal eating habits } \\
\text { - } & \text { Abnormal eating habits } \\
\text { - } & \text { Unhealthy snacking } \\
\text { - } & \text { Work stress and disordered eating due } \\
& \text { to long hours/workload }\end{array}$ & Nil \\
\hline $\begin{array}{l}\text { Physical features of the } \\
\text { workplace environment }\end{array}$ & $\begin{array}{ll}- & \text { Limited access to healthy food } \\
- & \text { Inadequate food storage and } \\
\text { preparation areas }\end{array}$ & $\begin{array}{ll}- & \text { Healthy food not offered on-site } \\
- & \text { Limited range of healthy options } \\
- & \text { Higher cost of healthy food on-site } \\
- & \text { Junk food vending machines only } \\
\text { option } \\
-\quad \text { Cafeterias too far from work space } \\
-\quad \text { Lack of microwaves, fridges, and food } \\
\text { preparation areas }\end{array}$ & 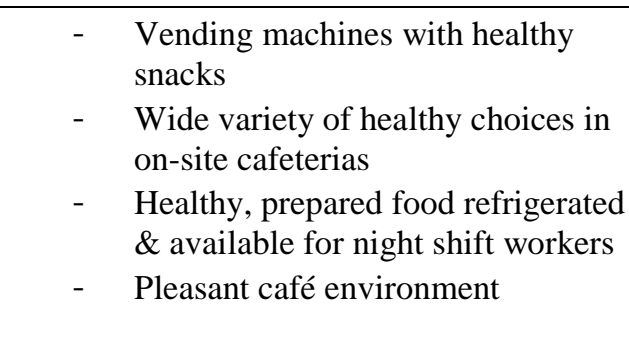 \\
\hline $\begin{array}{l}\text { Features of the workplace } \\
\text { social realm }\end{array}$ & $\begin{array}{ll}\text { - } & \text { Social interactions with } \\
\text { colleagues } \\
\text { - } & \text { Gifts from patients }\end{array}$ & $\begin{array}{ll}\text { - } & \text { Influence of colleagues to eat junk } \\
\text { food } \\
\text { - }\end{array}$ & $\begin{array}{l}\text { Meals shared with colleagues can } \\
\text { strengthen motivation to adopt } \\
\text { healthier habits }\end{array}$ \\
\hline
\end{tabular}




\begin{tabular}{|c|c|c|c|}
\hline Individual factors & $\begin{array}{ll}- & \text { Perception of weight status } \\
- & \text { Acknowledging/ recognising poor } \\
& \text { eating habits } \\
- & \text { Knowledge } \\
- & \text { Self-efficacy } \\
- & \text { Motivation }\end{array}$ & $\begin{array}{ll}- & \begin{array}{l}\text { Not perceiving own weight status } \\
\text { correctly }\end{array} \\
\text { - } & \text { Not recognising/ acknowledging poor } \\
\text { eating habits } \\
\text { - }\end{array}$ & Nil \\
\hline
\end{tabular}

